\title{
The analysis of the possibilities of fulfillment of EU carbon dioxide emission requirements through non-construction methods
}

\begin{abstract}
The paper presents comparison of new emission legislation related to vehicles of homologation category $M$ and $N$ introduced in the EU in recent years with the currently applicable regulations. The structure and form of the new legislation has been discussed along with the principles of new division of vehicles into light duty and heavy-duty vehicles. The authors put emphasis on the vehicle control in terms of emissions and emission related parameters (fuel consumption, engine power output, exhaust opacity).
\end{abstract}

Key words: combustion engine, exhaust emission, emission legislation

\section{Analiza możliwości spelnienia wymagań przepisów Unii Europejskiej dotyczących emisji dwutlenku węgla z pojazdów samochodowych za pomocą środków innych niż konstrukcyjne}

\begin{abstract}
W artykule przeprowadzono porównanie nowych przepisów dotyczacych emisji zanieczyszczeń dla pojazdów samochodowych kategorii homologacyjnych Mi N, wprowadzanych w UE w ostatnich kilku latach, z dotychczas obowiazujacymi. Omówiono strukturę i formę nowych przepisów oraz zasady nowego podziału pojazdów na lekkie i ciężkie. Nacisk położono na przepisy dotyczace kontroli pojazdów pod względem emisji zanieczyszczeń i cech zwiąanych z emisją (zużycie paliwa, moc silnika, zadymienie spalin).
\end{abstract}

Słowa kluczowe: silnik spalinowy, emisja spalin, przepisy homologacyjne

\section{Introduction}

In the European Union (EU) for many years emphasis has been put on the reduction of the emission of greenhouse gases including the emissions generated by transport (road transport in particular). The European Commission in 1995 adopted „Community Strategy to reduce $\mathrm{CO}_{2}$ emissions from cars". The strategy was based on three principles:

- Free declaration of the industry to reduce the emission from vehicles,

- Improvement of consumer information,

- Promotion of vehicles of low fuel consumption through introduction of tax incentives.

In 1998 the European Automobile Manufacturers' Association (ACEA)) undertook to reduce by 2008 the emissions of $\mathrm{CO}_{2}$ to $140 \mathrm{~g} / \mathrm{km}$ from new vehicles registered in the EU. In the following year the Japan Automobile Manufacturers Association JAMA and Korea Automobile Manufacturers Association KAMA drawing on ACEA declared to also reduce the emissions to $140 \mathrm{~g} / \mathrm{km}$ by 2009 .

In 2007 The EU adopted a new strategy related to the emission of carbon dioxide for light-duty vehicles - a category that includes passenger vehicles (homologation category M1) and light duty trucks (category N1). According to this strategy the reduction of the emission of this principal greenhouse gas is to be realized through introduction of legal requirements for the manufacturers. Such requirements are to be introduced because free declarations of the industry do not contribute to the reduction of the average emission of carbon dioxide to the required level from vehicles newly registered in the EU.

\section{Wprowadzenie}

W Unii Europejskiej (UE) od wielu lat duży nacisk kładzie się na ograniczenie emisji gazów cieplarnianych, w tym z transportu, w szczególności drogowego. Komisja Europejska w 1995 r. przyjęła „Community Strategy to reduce $\mathrm{CO}_{2}$ emissions from cars". Strategia ta była oparta na trzech zasadach:

- dobrowolnym zobowiązaniu przemysłu do ograniczenia emisji z samochodów osobowych,

- poprawie informacji dla konsumenta,

- promocji samochodów o małym zużyciu paliwa przez wprowadzenie zachęt podatkowych.

W roku 1998 stowarzyszenie ACEA (European Automobile Manufacturers' Association) zobowiązało się do ograniczenia do $2008 \mathrm{r}$. emisji $\mathrm{CO}_{2}$ do $140 \mathrm{~g} / \mathrm{km}$ z nowych samochodów osobowych rejestrowanych na terenie UE. W następnym roku stowarzyszenie JAMA (Japan Automobile Manufacturers' Association) oraz KAMA (Korea Automobile Manufacturers 'Association), wzorując się na ACEA, podjęły zobowiązania do ograniczenia tej emisji również do 140 $\mathrm{g} / \mathrm{km}$ do $2009 \mathrm{r}$.

W roku 2007 UE przyjęła nową strategię odnośnie do emisji dwutlenku węgla z tzw. pojazdów lekkich (light-duty vehicles), do których zalicza się m.in. samochody osobowe (kategoria homologacyjna M1) i samochody dostawcze (kategoria N1). Zgodnie z tą strategią ograniczenie emisji tego podstawowego gazu cieplarnianego ma nastąpić dzięki wprowadzeniu prawnych wymagań dla producentów. Wymagania takie mają być wprowadzone, gdyż dobrowolne zobowiązania przemysłu nie przyczynią się do obniżenia 
In order to implement the new, integrated EU strategy related to the emission of $\mathrm{CO}_{2}$ from light duty vehicles two legal acts have been adopted:

- Regulation 443/2009 [1], applicable to all vehicles in homologation category M1,

- Regulation 510/2011 [2], applicable to vehicles in homologation category $\mathrm{N} 1$ :

- of the reference mass not exceeding $2610 \mathrm{~kg}$,

- of the mass exceeding $2610 \mathrm{~kg}$ for which the homologation was extended, granted pursuant to regulation $715 / 2007$ [4] (according to this regulation there is a possibility of extending, without tests, of the homologation of vehicles in category M1, M2, N1 and N2 of reference mass not exceeding $2610 \mathrm{~kg}$ to vehicles in category N1 of reference mass not exceeding $2840 \mathrm{~kg}$ ).

The said regulations assume that meeting of the requirements set forth in them will be an effect of actions of design/ construction related activities leading to a reduction of the real emission of carbon dioxide in which the following are included:

- application of alternative powertrains (electric, hybrid),

- wider application of alternative fueling,

- improvements in vehicle technology.

From the analysis of the said regulations and legal acts cited there it results that in order to fulfill the requirements also other measures such as non-construction methods can be used. They do not contribute to the reduction of the emission of carbon monoxide but they influence the values of the requirements compliance indexes assumed in the regulations.

The aim of this study is the identification of the nonconstruction measures that the manufacturers can take in order to meet the requirements related to the emission of carbon dioxide set forth in the regulations and assessment of their potential effects.

\section{Requirements related to the emission of carbon dioxide set forth in the regulations}

Pursuant to the said regulations for vehicles made by a given manufacturer, average permitted road emission of $\mathrm{CO}_{2}$ is determined (specific emissions target). It is calculated as an average road emission of all vehicles manufactured by a given manufacturer and registered in a given calendar year in all the EU member states:

$$
\mathrm{E}_{\mathrm{CO} 2}^{\mathrm{PM}}=\frac{1}{\mathrm{n}} \sum_{\mathrm{i}=1}^{\mathrm{n}}\left(\mathrm{E}_{\mathrm{CO} 2}^{\mathrm{PV}}\right)_{\mathrm{i}}
$$

The notation assumed in the formulas (1)-(4): $\mathrm{E}_{\mathrm{CO} 2}^{\mathrm{PM}}-$ average permitted road emission of $\mathrm{CO}_{2}$ from vehicles of a given manufacturer, $\mathrm{g} / \mathrm{km} ;\left(\mathrm{E}_{\mathrm{CO} 2}^{\mathrm{PV}}\right)_{\mathrm{i}}-$ admissible road emission of $\mathrm{CO}_{2}$ for the $\mathrm{i}$-th vehicle, $\mathrm{g} / \mathrm{km} ; \mathrm{E}_{\mathrm{CO} 2}^{\mathrm{TM}}-$ average homologation road emission of $\mathrm{CO}_{2}$ from vehicles of a given manufacturer, $\mathrm{g} / \mathrm{km} ;\left(\mathrm{E}_{\mathrm{CO} 2}^{\mathrm{TV}}\right)_{\mathrm{i}}-$ road emission of $\mathrm{CO}_{2}$ of an i-th vehicle as per the certificate of conformity, $\mathrm{g} / \mathrm{km} ; \mathrm{M}$ - vehicle curb weight, $\mathrm{kg} ; \mathrm{M}_{0}$ - average weight of a vehicle depending on a category and the calculation średniej emisji dwutlenku węgla do wymaganego poziomu - z nowych samochodów rejestrowanych w UE.

W celu wdrożenia nowej, zintegrowanej strategii UE dotyczącej emisji $\mathrm{CO}_{2}$ z pojazdów lekkich przyjęto dwa akty prawne:

- rozporządzenie 443/2009 [1], dotyczące wszystkich samochodów kategorii homologacyjnej M1,

- rozporządzenie 510/2011 [2], dotyczące samochodów kategorii homologacyjnej N1:

- o masie odniesienia nieprzekraczającej $2610 \mathrm{~kg}$,

- o masie przekraczającej $2610 \mathrm{~kg}$, na które rozszerzono homologację udzieloną według rozporządzenia 715/2007 [4] (zgodnie z tym rozporządzeniem istnieje możliwość rozszerzenia bez badań homologacji pojazdów kategorii M1, M2, N1 i N2 o masie odniesienia nieprzekraczającej $2610 \mathrm{~kg}$ na m.in. samochody kategorii N1 o masie odniesienia nieprzekraczającej $2840 \mathrm{~kg})$.

Wymienione rozporządzenia zakładają, że spełnienie ustalonych w nich wymagań nastąpi w wyniku działań o charakterze „,konstrukcyjnym”, prowadzących do obniżenia rzeczywistej emisji dwutlenku węgla, do których zalicza się:

- zastosowanie napędów alternatywnych (elektrycznych, hybrydowych),

- szersze zastosowanie zasilania paliwami alternatywnymi,

- doskonalenie pojazdów konwencjonalnych (improvements in vehicle technology).

$\mathrm{Z}$ analizy wymienionych rozporządzeń, a także aktów prawnych w nich przywoływanych wynika jednak, że do spełnienia wymagań mogą być także wykorzystane środki, które można określić jako „niekonstrukcyjne”. Nie przyczyniają się one do obniżenia rzeczywistej emisji dwutlenku węgla, lecz wpływają na wartości wskaźników przyjętych w rozporządzeniach do oceny zgodności z wymaganiami.

Celem niniejszego opracowania jest identyfikacja środków niekonstrukcyjnych, które producenci mogą podjąć w celu spełnienia wymagań odnośnie do emisji dwutlenku węgla ustalonych w rozporządzeniach i oszacowanie ich potencjalnego efektu.

\section{Wymagania odnośnie do emisji dwutlenku węgla ustalone w rozporządzeniach}

Zgodnie z wymienionymi rozporządzeniami wyznacza się dla producenta średnią dopuszczalną emisję drogową $\mathrm{CO}_{2} \mathrm{z}$ jego pojazdów (specific emissions target). Oblicza się ją jako wartość średnią dopuszczalnej emisji drogowej wszystkich samochodów wyprodukowanych przez danego producenta i zarejestrowanych w danym roku kalendarzowym we wszystkich państwach członkowskich UE - wzór (1).

Oznaczenia przyjęte we wzorach (1)-(4): $\mathrm{E}_{\mathrm{CO} 2}^{\mathrm{PM}}$ - średnia dopuszczalna emisja drogowa $\mathrm{CO}_{2}$ pojazdów danego producenta, g/km; $\left(\mathrm{E}_{\mathrm{CO} 2}^{\mathrm{PV}}\right)_{\mathrm{i}}$ - dopuszczalna emisja drogowa $\mathrm{CO}_{2}$ dla i-tego pojazdu, g/km; $\mathrm{E}_{\mathrm{CO} 2}^{\mathrm{TM}}$ - średnia homologacyjna emisja drogowa $\mathrm{CO}_{2}$ pojazdów danego producenta, $\mathrm{g} / \mathrm{km}$; 
period, $\mathrm{kg} ; \mathrm{n}$ - number of all vehicles manufactured by a given manufacturer and registered in a given calendar year in all EU member states.

Permissible specific emissions of $\mathrm{CO}_{2}$ for an i-th vehicle depend on the vehicle curb weight i.e. the vehicle weight plus $75 \mathrm{~kg}$. The dependence between the permissible road emission and this weight is determined with the formulas (valid until 2020):

- for the vehicles in category M1:

$$
\left(\mathrm{E}_{\mathrm{CO} 2}^{\mathrm{PV}}\right)_{\mathrm{i}}=130+0.0457\left(\mathrm{M}-\mathrm{M}_{0}\right)
$$

- for the vehicles in category $\mathrm{N} 1$ :

$$
\left(\mathrm{E}_{\mathrm{CO} 2}^{\mathrm{PV}}\right)_{\mathrm{i}}=175+0.093\left(\mathrm{M}-\mathrm{M}_{0}\right)
$$

For category M1 in the period from 2012 to 2015 the value $\mathrm{M}_{0}$ amounts to $1372 \mathrm{~kg}$ and for $\mathrm{N} 1$ in the period from 2014 to 2017 amounts to $1706 \mathrm{~kg}$; after these dates it can be verified.

The average permissible road emission for a given vehicle manufacturer is compared with the average homologation road emission for a given manufacturer calculated as a value of the average road emission specified in the certificate of conformity of all the vehicles manufactured by a given manufacturer and registered in all the EU member states as per the formula below:

$$
\mathrm{E}_{\mathrm{CO} 2}^{\mathrm{TM}}=\frac{1}{\mathrm{n}} \sum_{\mathrm{i}=1}^{\mathrm{n}}\left(\mathrm{E}_{\mathrm{CO} 2}^{\mathrm{TV}}\right)_{\mathrm{i}}
$$

It is expected that as a result of the introduced requirements a reduction of the average permissible road emission of carbon dioxide will take place for new passenger vehicles for the whole EU to at least a level specified in Table 1.

The certificate of conformity is issued following the certificate of homologation as per directive 2007/46 [3]. The value of the road emission of carbon dioxide specified therein is determined by the homologation tests realized according to regulation 715/2007 [4] and implementation regulation applicable in the time of homologation (currently 692/2008 [5]).

Table 1. Expected average road emission of $\mathrm{CO}_{2}$ from new vehicles in homologation category $\mathrm{M} 1$ and $\mathrm{N} 1$

Tabela 1. Oczekiwana średnia emisja drogowa $\mathrm{CO}_{2}$ nowych samochodów kategorii homologacyjinych $\mathrm{Ml}$ i N1

\begin{tabular}{|c|c|c|}
\hline $\begin{array}{c}\text { Vehicle category/ } \\
\text { kategoria pojazdów }\end{array}$ & Period/okres & $\begin{array}{c}\text { Road emission/emisja } \\
\text { drogowa } \mathrm{CO}_{2}[\mathrm{~g} / \mathrm{km}]\end{array}$ \\
\hline \multirow{2}{*}{ M1 } & $2015-2019$ & 130 \\
\cline { 2 - 3 } & $2020-$ & 95 \\
\hline \multirow{2}{*}{ N1 } & $2017-2019$ & 175 \\
\cline { 2 - 3 } & $2020-$ & 147 \\
\hline
\end{tabular}

It is noteworthy that in general the road emissions of carbon dioxide from an i-th vehicle given in the certificate of conformity $\left(\mathrm{E}_{\mathrm{CO} 2}^{\mathrm{TV}}\right)_{\mathrm{i}}$ may differ from the actual road emis-
$\left(\mathrm{E}_{\mathrm{CO} 2}^{\mathrm{TV}}\right)_{\mathrm{i}}$ - emisja drogowa $\mathrm{CO}_{2}$ i-tego pojazdu według świadectwa zgodności, $\mathrm{g} / \mathrm{km} ; \mathrm{M}$ - masa pojazdu w stanie gotowym do jazdy, $\mathrm{kg} ; \mathrm{M}_{0}$ - masa średnia pojazdu zależna od kategorii i okresu obliczeniowego, kg; n-liczba wszystkich samochodów wyprodukowanych przez danego producenta $\mathrm{i}$ zarejestrowanych $\mathrm{w}$ danym roku kalendarzowym we wszystkich państwach członkowskich UE.

Wartości dopuszczalne emisji drogowej (permitted specific emissions) $\mathrm{CO}_{2}$ dla i-tego samochodu są uzależnione od jego masy w stanie gotowym do jazdy, czyli masy własnej zwiększonej o $75 \mathrm{~kg}$. Zależność między wartością dopuszczalną emisji drogowej a tą masą jest określona wzorami (ważnymi do 2020 r.): dla samochodów kategorii M1 (2a), dla samochodów kategorii N1 (2b).

Dla kategorii M1 w okresie od 2012 do 2015 r. wartość M0 wynosi $1372 \mathrm{~kg}$, natomiast dla N1 w okresie od 2014 do 2017 r. jest równa $1706 \mathrm{~kg}$; po tych datach może zostać zweryfikowana.

Średnią dopuszczalną emisję drogową dla producenta pojazdów porównuje się ze średnią homologacyjną emisją drogową dla producenta, obliczoną jako wartość średnią emisji drogowej podanej w świadectwie zgodności (certificate of conformity) wszystkich samochodów wyprodukowanych przez danego producenta i zarejestrowanych $\mathrm{w}$ danym roku kalendarzowym we wszystkich państwach członkowskich UE, według wzoru (3).

Oczekuje się, że w wyniku wprowadzonych wymagań nastąpi obniżenie średniej dopuszczalnej drogowej emisji dwutlenku węgla dla producenta $\mathrm{z}$ nowych samochodów osobowych dla całej UE co najmniej do poziomu podanego w tabeli 1.

Świadectwo zgodności wydane jest na podstawie świadectwa homologacji zgodnie z dyrektywą 2007/46 [3]. Podana w nim wartość emisji drogowej dwutlenku węgla jest określona w wyniku badań homologacyjnych prowadzonych według rozporządzenia 715/2007 [4] i aktualnego w czasie homologacji rozporządzenia wdrażającego (obecnie 692/2008 [5]).

Należy podkreślić, że w ogólnym przypadku emisja drogowa dwutlenku węgla i-tego pojazdu podana w świadectwie zgodności $\left(\mathrm{E}_{\mathrm{CO} 2}^{\mathrm{TV}}\right)_{\mathrm{i}}$ może różnić się od rzeczywistej emisji drogowej i-tego pojazdu $\left(\mathrm{E}_{\mathrm{CO} 2}^{\mathrm{RV}}\right)_{\mathrm{i}}$, określonej według metody badań ustalonej w rozporządzeniu wdrażającym rozporządzenie 715/2007.

Uznaje się, że producent spełnia wymagania ustalone w rozporządzeniu 443/2009 dla samochodów kategorii homologacyjnej M1 i rozporządzeniu 510/2011 dla N1, gdy spełniony jest warunek (4).

Jeśli warunek (4) nie jest spełniony, producent płaci kary pieniężne obliczone według zasad podanych $\mathrm{w}$ odpowiednim rozporządzeniu. Kary są stosunkowo wysokie i wzrastają stopniowo do wartości docelowych, które wynoszą dla jednego samochodu 95 Euro/ $1 \mathrm{~g} \mathrm{CO}_{2}$.

W celu określenia średniej homologacyjnej $\mathrm{E}_{\mathrm{CO} 2}^{\mathrm{TM}} \mathrm{i}$ średniej dopuszczalnej $\mathrm{E}_{\mathrm{CO} 2}^{\mathrm{PM}}$ emisji drogowej dwutlenku węgla, pojazdy wyprodukowane przez danego producenta i 
sion of that $\mathrm{i}$-th vehicle $\left(\mathrm{E}_{\mathrm{CO} 2}^{\mathrm{RV}}\right)_{i}$, determined according to the method of research set forth in the regulation implementing regulation $715 / 2007$.

It is assumed that the manufacturer meets the requirements set forth in regulation 443/2009 for vehicles in homologation category M1 and regulation 510/2011 for N1 when:

$$
\mathrm{E}_{\mathrm{CO} 2}^{\mathrm{TM}} \leq \mathrm{E}_{\mathrm{CO} 2}^{\mathrm{PM}}
$$

If condition (4) is not fulfilled, the manufacturers sustain financial penalties calculated according to the principles set forth in appropriate regulations. The penalties are relatively high and gradually grow to the target values, which are for a single vehicle 95 Euro/ $1 \mathrm{~g} \mathrm{CO}_{2}$.

In order to determine the average homologation $\mathrm{E}_{\mathrm{CO} 2}^{\mathrm{TM}}$ and average permissible $\mathrm{E}_{\mathrm{CO} 2}^{\mathrm{PM}}$ road emission of carbon monoxide, the vehicles manufactured by a given manufacturer and registered in a given calendar year in all EU member states are divided into types, and these again are divided into variants and the latter into versions (Table 2). Version is the smallest group of vehicles for which the values $\left(\mathrm{E}_{\mathrm{CO} 2}^{\mathrm{TV}}\right)_{i}$ and $\left(\mathrm{E}_{\mathrm{CO} 2}^{\mathrm{PV}}\right)_{i}$ are determined.

According to the said regulations the requirements will be gradually implemented starting from 2012 for vehicles in category M1 and from 2014 for category N1. From 2015 for M1 and 2017 for N1 they will be applicable to all new vehicles.

In 2010 the average homologation road emission of carbon dioxide from all new vehicles in category M1 registered in the EU was $140 \mathrm{~g} / \mathrm{km}$ (Fig. 1). In order to meet the requirements set forth in regulation 443/2009 the emission should be reduced by 2015 by $10 \mathrm{~g} / \mathrm{km}$ on average i.e. by $7.2 \%$.

For vehicles in category N1 there are no official data related to the road emission of carbon dioxide as such emission have not been monitored. The available data come from databases of the homologation institutions in different countries. The arithmetic average road emission of the homologated types is estimated in the range from 185 to 230 $\mathrm{g} / \mathrm{km}$ depending on the data source. In general, it is assumed that the homologation average determined according to the principles specified in regulation 510/2011 is approximately $205-215 \mathrm{~g} / \mathrm{km}$, thus, in order to meet the requirements the emission has to be reduced by 2017 by at least approximately $30-40 \mathrm{~g} / \mathrm{km}$, i.e. by $14-19 \%$.

There are huge differences among the average emissions of carbon dioxide for different manufacturers (Fig. 2). The zarejestrowane w danym roku kalendarzowym w państwach członkowskich UE są dzielone na typy, te z kolei na warianty, a te ostatnie na wersje (tab. 2). Wersja jest najmniejszą grupa pojazdów, dla której określa się wartości $\left(\mathrm{E}_{\mathrm{CO} 2}^{\mathrm{TV}}\right)_{\mathrm{i}} \mathrm{i}$ $\left(\mathrm{E}_{\mathrm{CO} 2}^{\mathrm{PV}}\right)_{\mathrm{i}}$.

Zgodnie z wymienionymi rozporządzeniami wymagania będą stopniowo wdrażane, począwszy od 2012 r. dla samochodów kategorii M1 i od 2014 r. dla kategorii N1. Od roku 2015 dla M1 i 2017 r. dla N1 będą one dotyczyły wszystkich nowych pojazdów.

W roku 2010 średnia homologacyjna emisja drogowa dwutlenku węgla z wszystkich nowych samochodów kategorii M1 zarejestrowanych w UE wynosiła 140 g/km (rys. 1). W celu spełnienia wymagań ustalonych w rozporządzeniu

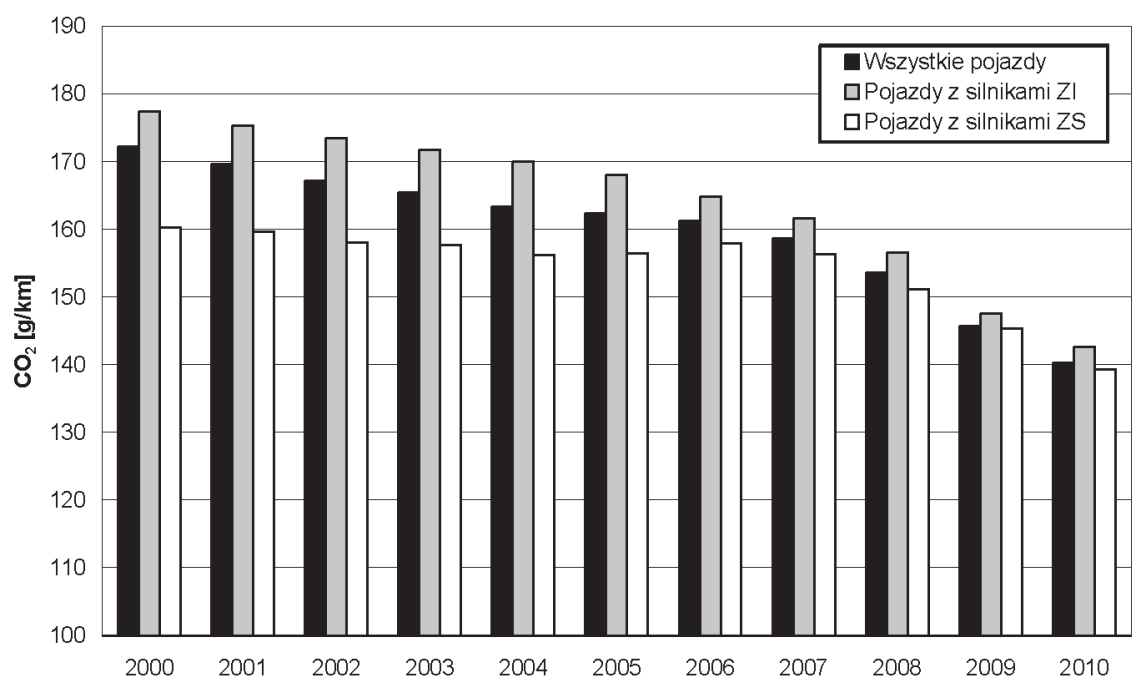

Fig. 1. Average homologation road emission of carbon dioxide from new vehicles in category M1 in the period from 2000 to 2010 in the EU [6]

w okresie od 2000 do 2010 r. w UE [6]

443/2009 powinna ona być zmniejszona do 2015 r. średnio co najmniej o $10 \mathrm{~g} / \mathrm{km}$, tj. o $7,2 \%$.

Dla pojazdów kategorii N1 nie ma oficjalnych danych dotyczących emisji drogowej dwutlenku węgla, gdyż monitoring nie był dotychczas prowadzony. Dostępne informacje pochodzą z bazy danych organów homologacyjnych w różnych państwach. Średnia arytmetyczna emisja drogowa homologowanych typów jest szacowana w przedziale od 185 do $230 \mathrm{~g} / \mathrm{km}$ w zależności od źródła danych. Na ogół przyjmuje się, że średnia homologacyjna określona według zasad podanych w rozporządzeniu 510/2011 wynosi około 205-215 g/km, a zatem w celu spełnienia wymagań niezbędne jest jej zmniejszenie do 2017 r. co najmniej o około 30-40 g/km, tj. o 14-19\%.

Między średnią emisją drogową dwutlenku węgla dla producentów samochodów występują bardzo duże różnice (rys. 2). Stopień zmniejszenia tej emisji niezbędny w celu spełnienia wymagań jest różny dla poszczególnych z nich. 


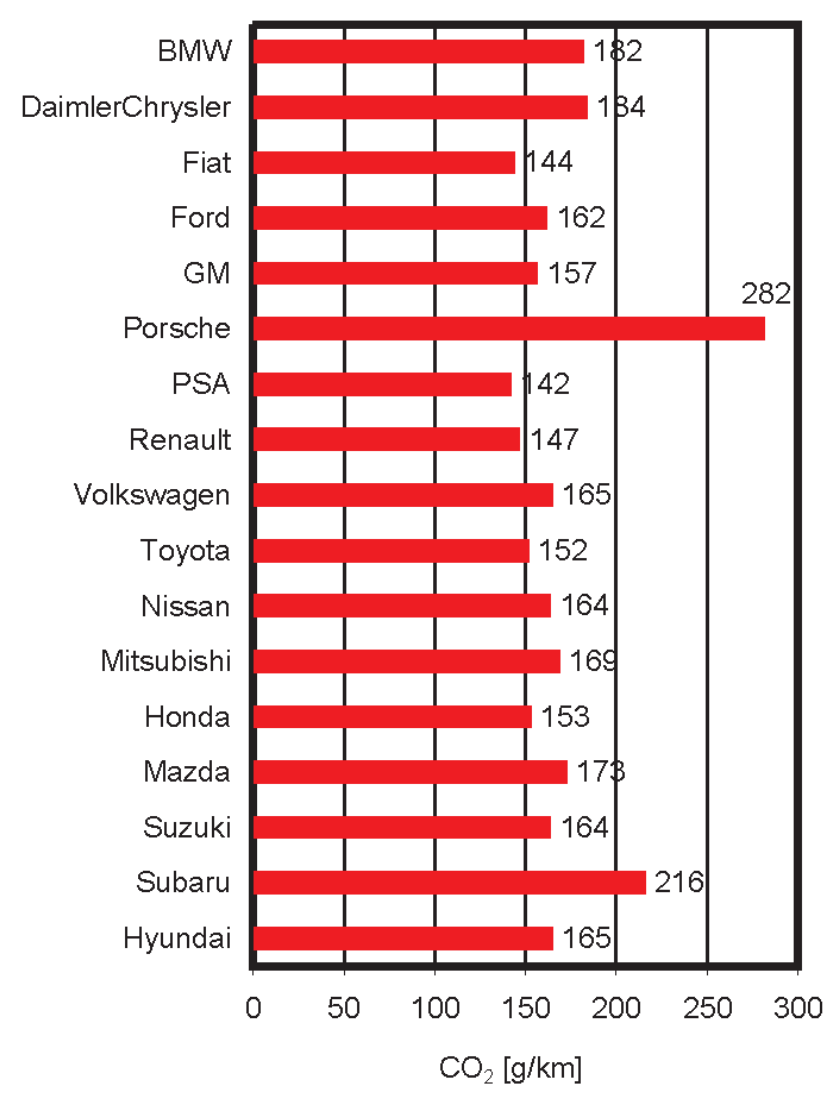

Fig. 2. Average homologation road emission of carbon dioxide from new vehicles of selected manufacturers [7]

Rys. 2. Średnia homologacyjna emisja drogowa dwutlenku węgla nowych pojazdów wybranych producentów [7]

rate of reduction of this emission necessary to meet the requirements is different for individual manufacturers.

\section{Homologacja samochodów pod względem emisji dwutlenku węgla}

Zasady homologacji samochodów lekkich pod względem emisji zanieczyszczeń i cech, które można określić jako „okołoemisyjne”, w tym emisji drogowej dwutlenku węgla, są ustalone w rozporządzeniu 692/2008 [5]. Nie podaje ono jednak szczegółowego opisu metody pomiaru, lecz określa ją przez odwołanie do odpowiednich przepisów w regulaminach EKG ONZ. W odniesieniu do dwutlenku węgla metoda ta jest ustalona $\mathrm{w}$ regulaminie 101 [8].

Metoda określania emisji drogowej dwutlenku węgla z pojazdów lekkich podana w rozporządzeniu 692/2008 i regulaminie 101 jest ujednolicona $\mathrm{z}$ ustaloną w teście typu I, do określania emisji drogowej zanieczyszczeń kontrolowanych, czyli stosowne pomiary stężeń przeprowadza się na hamowni podwoziowej w cyklu NEDC, po rozruchu zimnego silnika, stosując układ CVS. Różnica polega na tym, że mierzy się dodatkowo stężenie dwutlenku węgla.

Homologacji podlega typ pojazdu jednak nie w rozumieniu dyrektywy 2007/46 (tab. 2), lecz w rozumieniu rozporządzenia 692/2008. Definicja typu według tego rozporządzenia jest zupełnie różna od podanej w tabeli 2 .

Zasada określenia wartości emisji drogowej dwutlenku węgla typu pojazdu przyjętej do celów homologacji, podanej w świadectwie homologacji a następnie w świadectwie zgodności, jest następująca. Wykonuje się jeden test. Wartość emisji jest równa podanej przez producenta, jeśli ta ostatnia nie przekracza więcej niż 4\% wartości określonej w wyniku badań. Jeśli następuje przekroczenie, wykonuje się drugi test. Jeśli średnia z tych dwóch testów nie przekracza więcej niż $4 \%$ wartości określonej w wyniku badań, przyjmuje się wartość podaną przez producenta. Jeśli także następuje przekroczenie, wykonuje się trzeci test i jako wartość homologacyjną przyjmuje się średnią z trzech przeprowadzonych testów.

Table 2. Definitions of a 'vehicle type', 'vehicle variant' and 'vehicle version' according to directive 2007/46 for vehicles in category M1 Tabela 2. Definicje terminów ,typ pojazdu”, ,, wariant pojazdu” i ,, wersja pojazdu” wedtug dyrektywy 2007/46 dla pojazdów kategorii M1

\begin{tabular}{|c|c|c|}
\hline \multicolumn{3}{|c|}{ Homologation category/kategoria homologacyjna M1 } \\
\hline $\begin{array}{l}\text { 'Type' covers vehicles that are the same } \\
\text { in terms of the following characteristics/ } \\
\text { „Typ” obejmuje pojazdy nieróżniace się } \\
\text { między soba pod względem następuja- } \\
\text { cych cech: } \\
\text { a) manufacturer/producent, } \\
\text { b) type as provided by the manufac- } \\
\text { turer/oznaczenie typu nadane przez } \\
\text { producenta, } \\
\text { c) main design and construction charac- } \\
\text { teristics/główne cech konstrukcyjne: } \\
\text { - frame/platform/ podwozie/plyta } \\
\text { podtogowa } \\
\text { - type of engine (combustion/electric/ } \\
\text { hybrid)/rodzaj silnika (spalinowy/ } \\
\text { elektryczny/hybrydowy) }\end{array}$ & $\begin{array}{l}\text { 'Variant' covers vehicles that are the same in } \\
\text { terms of the following characteristics/,,Wa- } \\
\text { riant”' obejmuje pojazdy nieróżniace się mię- } \\
\text { dzy soba pod względem następujących cech: } \\
\text { a) type of body/rodzaj nadwozia, } \\
\text { b) engine/silnik: } \\
\text { - principle of operation: SI, CI, four stroke, } \\
\text { two stroke/zasada działania: ZI, ZS, } \\
\text { czterosuwowy, dwusuwowy, } \\
\text { - cylinder number and configuration/liczba i } \\
\text { układ cylindrów, } \\
\text { - power output (the greatest can be } 30 \% \\
\text { higher than the lowest)/moc (największa } \\
\text { może być o 30\% większa niż najmniejsza), } \\
\text { - displacement (the greatest can be } 20 \% \text { hi- } \\
\text { gher than the lowest)/pojemność skokowa } \\
\text { (największa może być o 20\% większa niż } \\
\text { najmniejsza), } \\
\text { c) driven axles (number and configuration, } \\
\text { kinematic pairs)/osie napędzane } \\
\text { d) steered axles (number and configuration)/ } \\
\text { osie kierowane (liczba i położenie) }\end{array}$ & $\begin{array}{l}\text { 'Version' covers vehicles the configuration of which is } \\
\text { determined by the manufacturer in a detailed technical } \\
\text { description; within one version we cannot combine } \\
\text { vehicles that differ in terms of the following charac- } \\
\text { teristics/,,Wersja” obejmuje pojazdy o kompletacji } \\
\text { ustalonej przez producenta w szczegółowym opisie } \\
\text { technicznym; w ramach wersji nie można łaczyć } \\
\text { pojazdów różniących się między soba pod względem } \\
\text { następujacych cech: } \\
\text { - gross vehicle weight/maksymalnej masy całkowitej, } \\
\text { - engine displacement/pojemności skokowej silnika, } \\
\text { - maximum power output/mocy maksymalnej, } \\
\text { - type of transmission and number of gears/typu skrzy- } \\
\text { ni biegów i liczby przełożeń, } \\
\text { - seating capacity/maksymalnej liczby miejsc } \\
\text { siedzacych }\end{array}$ \\
\hline
\end{tabular}




\section{Vehicle homologation in the aspect of carbon dioxide emission}

The principles of homologation of light duty vehicles in the aspect of exhaust emission referred to as 'emissionrelated' including the emission of carbon dioxide are set forth in regulation 692/2008 [5]. It does not, however, provide a detailed description of the measurement method but determines it through referring to appropriate legislation in the EEC UN regulations. In reference to carbon dioxide this method is specified in regulation 101 [8].

The method of determining of the road emission of carbon dioxide from light duty vehicles specified in regulation 692/2008 and regulation 101 is unified with the method set forth in test type I for the determining of the controlled emissions, i.e. individual measurements of concentrations are performed on chassis dynamometers in the NEDC cycle after cold start using a CVS system. The difference is that, additionally, the concentration of carbon dioxide is measured.

Homologation pertains to a vehicle but only as interpreted by regulation $692 / 2008$ not as interpreted by directive $2007 / 46$ (Table 2). The definition of type according to this regulation is entirely different than that given in Table 2 .

The principle of determining of the value of the road emission of carbon dioxide of a type of vehicle assumed for the purposes of homologation given in the certificate of homologation and then in the certificate of conformity is as follows: a single test is carried out. The value of the emission equals to that given by the manufacturer if the latter does not exceed more than $4 \%$ of the value determined by test. If there is excess, another test is carried out. If the average from these two tests does not exceed more than $4 \%$ of the value determined in the tests the value specified by the manufacturer is assumed. If the value is in excess again a third test is carried out and the homologation value is the one being the average of these three tests.

There is a possibility of extending of the homologation in terms of road emission of carbon dioxide for a given type of vehicles as understood in regulation 692/2008 to vehicles of the same or different type that differ from the homologated vehicles in the following:

- reference mass,

- gross vehicle weight,

- type of body (for category M1 - sedan, hatchback, station wagon, coupe, convertible, multitask, and for category N1 - dropside, van).

The extension can take place if the road emission of carbon dioxide determined by an authorized technical unit does not differ from the homologation value more than:

$-4 \%$ for category M1,

$-6 \%$ for category $\mathrm{N} 1$.

For category N1 there is a possibility of homologating a family of vehicles. By this term we understand vehicles of the same manufacturer, that are the same in terms of several engine parameters (displacement and power output), reference mass (lower by maximum $220 \mathrm{~kg}$ than the lowest in the family), frontal area (smaller by maximum $15 \%$ than the smallest in the family).
Istnieje możliwość rozszerzenia homologacji w zakresie emisji drogowej dwutlenku węgla udzielonej dla danego typu samochodów w rozumieniu rozporządzenia 692/2008 na pojazdy tego samego lub innego typu różniące się od homologowanego pod względem:

- masy odniesienia,

- dopuszczalnej masy całkowitej,

- rodzaju nadwozia (dla kategorii M1 - sedan, hatchback, kombi, coupe, kabriolet, wielozadaniowe, dla kategorii N1 - skrzyniowe, van).

Rozszerzenie może nastąpić, jeśli emisja drogowa dwutlenku węgla określona przez jednostkę techniczną upoważnioną do prowadzenia badań nie różni się od wartości homologacyjnej więcej niż:

$-4 \%$ dla kategorii M1,

$-6 \%$ dla kategorii N1.

Dla kategorii N1 istnieje możliwość homologacji rodziny samochodów. Pod tym pojęciem rozumie się samochody tego samego producenta, które nie różnią się pod względem m.in. wybranych cech silnika (pojemność skokowa i moc), masy odniesienia (mniejsza nie więcej niż $220 \mathrm{~kg}$ od najmniejszej w rodzinie), powierzchni czołowej (mniejsza nie więcej niż $15 \%$ od najmniejszej w rodzinie).

Rozporządzenie 692/2008 podaje dwie metody homologacji rodziny pojazdów kategorii N1 pod względem emisji drogowej dwutlenku węgla.

Przy homologacji według pierwszej z tych metod wartość homologacyjna emisji jest jednakowa dla wszystkich członków rodziny. W celu jej określenia wybiera się do badań samochód, którego emisję uważa się za największą $\mathrm{w}$ rodzinie.

Istnieje możliwość rozszerzenia takiej homologacji bez badań na samochody, które mają m.in.:

- masę odniesienia większą nie więcej niż $110 \mathrm{~kg}$,

- mniejsze przełożenie układu napędowego niż samochód badany.

W drugiej metodzie homologacji rodziny pojazdów kategorii N1 producent deklaruje dla wszystkich typów samochodów wartości emisji drogowej dwutlenku węgla. Do badań wybiera się samochód o najmniejszej i największej wartości. Dla obu pojazdów określa się emisję. Jeśli na podstawie badań można przyjąć wartości deklarowane przez producenta dla tych pojazdów, to uznaje się także wartości deklarowane dla pozostałych członków rodziny. $\mathrm{W}$ przeciwnym razie przeprowadza się badania wszystkich pozostałych członków rodziny. Jako wartości homologacyjne przyjmuje się wyniki badań.

Homologację udzieloną według metody drugiej można rozszerzyć bez badań na innych członków rodziny, jeśli jednostka techniczna prowadząca badania uznaje, że ich emisja drogowa $\mathrm{CO}_{2}$ mieści się w przedziale ustalonym w wyniku homologacji dwóch wyżej wymienionych pojazdów.

\section{Identyfikacja środków niekonstrukcyjnych}

\subsection{Uwagi ogólne}

Środki niekonstrukcyjne stosowane w celu spełnienia wymagań odnośnie do emisji drogowej dwutlenku węgla 
Regulation 692/2008 specifies two methods of homologation of a family of vehicles in category N1 in terms of road emission of carbon dioxide.

While homologating with the first of these two methods the homologation value of the emission is the same for all vehicles from the family. In order to determine that value a vehicle of the highest emission level in the family is selected from that family.

There is a possibility of extending of such a homologation without testing to vehicles with:

- reference mass higher by maximum $110 \mathrm{~kg}$,

- lower gear ratio than the tested vehicle.

In the second method of homologation of a family of vehicles in category $\mathrm{N} 1$ the manufacturer declares for all vehicle types the values of the road emission of carbon dioxide. For the test a vehicle with the highest and the lowest emission is selected. For both vehicles the emission is determined. If based on the tests the values declared by the manufacturer for these vehicles can be assumed then the values declared for the rest of the vehicle family are accepted. Otherwise testing of all the outstanding vehicles from that family is carried out. The results of test are assumed as the homologation values.

Homologation carried out with the second method can be extended to other vehicles of the same family without testing if the certifying technical unit recognizes that their road emission of $\mathrm{CO}_{2}$ remains in the range determined following the homologation of the two above-mentioned vehicles.

\section{Identification of the non-construction measures}

\subsection{General remarks}

Non-construction methods applied in order to meet the requirements related to the road emission of carbon dioxide can be divided into two basic groups. The first one of those methods results in an increase in the average permissible emission of carbon dioxide for the manufacturer $\mathrm{E}_{\mathrm{CO} 2}^{\mathrm{PM}}$. They result from the principles of evaluation set forth in regulations 403/2009 and 510/2011. The other group are measures whose effect is the reduction of the average homologation road emission of carbon dioxide for the manufacturer. They are divided into measures resulting from:

- the principles of homologation,

- the method of determining of the emission of this component.

Both the increase in $\mathrm{E}_{\mathrm{CO} 2}^{\mathrm{PM}}$ and the decrease in $\mathrm{E}_{\mathrm{CO} 2}^{\mathrm{TM}}$ are a result of a change of respective values $\left(\left(\mathrm{E}_{\mathrm{CO} 2}^{\mathrm{PV}}\right)_{i}\right.$ and $\left.\left(\mathrm{E}_{\mathrm{CO} 2}^{\mathrm{TV}}\right)_{i}\right)$ for individual versions into which the vehicles manufactured by a given manufacturer were divided.

\subsection{Measures of increasing of the permissible road emission of carbon dioxide}

In this part the analysis of the measures was carried out going on the assumption that the value of the road emission of carbon dioxide determined during the homologation tests is equal to the actual one. The possibility of increasing of the maximum permissible road emission of $\mathrm{CO}_{2}$ in a given version of vehicles results from the principles of evaluation można podzielić na dwie podstawowe grupy. Do pierwszej zalicza się te z nich, które powodują zwiększenie średniej dopuszczalnej emisji drogowej dwutlenku węgla dla producenta $\mathrm{E}_{\mathrm{CO} 2}^{\mathrm{PM}}$. Wynikają one $\mathrm{z}$ zasad oceny ustalonej $\mathrm{w}$ rozporządzeniach 403/2009 i 510/2011. Do drugiej grupy należą środki, których efektem jest zmniejszenie średniej homologacyjnej emisji drogowej dwutlenku węgla dla producenta. Dzielą się one z kolei na środki wynikające z:

- zasad homologacji,

- metody określenia emisji tego zanieczyszczenia.

Zarówno zwiększenie $\mathrm{E}_{\mathrm{CO} 2}^{\mathrm{PM}}$, jak i zmniejszenie $\mathrm{E}_{\mathrm{CO} 2}^{\mathrm{TM}}$ są wynikiem zmian odpowiednich wartości $\left(\left(\mathrm{E}_{\mathrm{CO} 2}^{\mathrm{PV}}\right)_{\mathrm{i}} \mathrm{i}\left(\mathrm{E}_{\mathrm{CO} 2}^{\mathrm{TV}}\right)_{\mathrm{j}}\right)$ dla poszczególnych wersji, na które podzielono pojazdy wytworzone przez danego producenta.

\section{2. Środki zwiększenia dopuszczalnej emisji drogowej dwutlenku węgla}

W niniejszym punkcie analizę środków przeprowadzono przy założeniu, że wartość emisji drogowej dwutlenku węgla określona podczas badań homologacyjnych jest równa rzeczywistej. Możliwość zwiększenia dopuszczalnej emisji drogowej $\mathrm{CO}_{2}$ z danej wersji samochodów wynika z zasad oceny, które występują zarówno w rozporządzeniu 443/2009, jak i 510/2011. Zgodnie z tymi zasadami, jeśli w świadectwie zgodności nie występuje jedna określona wartość masy pojazdu w stanie gotowym do jazdy, lecz przedział, w którym może się ona znajdować, to do określenia $\left(\mathrm{E}_{\mathrm{CO} 2}^{\mathrm{PV}}\right)_{i}$ należy przyjąć wartość maksymalną tego przedziału. W celu wykorzystania tej możliwości producent powinien tak zdefiniować daną wersję, by zawierała ona pojazdy o różnej masie w stanie gotowym do jazdy, i w dokumentach homologacyjnych określić przedział tego parametru.

Dla kategorii M1 włączenie do jednej wersji samochodów różniących się pod względem maksymalnej masy całkowitej jest zabronione (tab. 2), natomiast różniących się pod względem masy w stanie gotowym do jazdy jest dopuszczalne. Dla kategorii N1 nie ma warunków odnośnie do masy pojazdów.

\section{3. Środki zmniejszenia homologacyjnej emisji drogowej dwutlenku węgla wynikające $\mathrm{z}$ zasad homologacji}

Zmniejszenie emisji drogowej dwutlenku węgla według świadectwa homologacji $\left(\mathrm{E}_{\mathrm{CO} 2}^{\mathrm{TV}}\right)_{\mathrm{i}}$ dla danej wersji samochodów wynika z zasady ustalania wartości homologacyjnej podanej w rozporządzeniu 692/2008 i regulaminie 101 (pkt 3). Przed badaniami homologacyjnymi producent dysponuje na ogół pewną liczbą samochodów danego typu w rozumieniu rozporządzenia 692/2008. W celu wykorzystania tej zasady producent powinien przeprowadzić wstępne badania emisji drogowej $\mathrm{CO}_{2} \mathrm{z}$ tych samochodów, zgodnie $\mathrm{z}$ metodą ustaloną $\mathrm{w}$ regulaminie 101, przedstawić do badań homologacyjnych ten z nich, który cechuje się niską emisją i zadeklarować wartość o 4\% mniejszą. Jednym z kryteriów wyboru samochodu do badań homologacyjnych jest masa odniesienia tego samochodu. 
that are specified in both regulations 443/2009 and 510/2011. Following these principles, if in the certificate of conformity there is no single determined value of the vehicle curb weight but only a range within which it can be then for the determination of $\left(\mathrm{E}_{\mathrm{CO} 2}^{\mathrm{PV}}\right)_{i}$ we need to assume the maximum value of this range. In order to use this possibility the manufacturer should define a given version in such a way that it contains vehicles of different curb weights and in the homologation documentation determine the range of this parameter.

For category M1 inclusion into one version of vehicles that differ in terms of gross vehicle weight is forbidden (Table 2) but differences in terms of curb weight are permissible. For category N1 there are not weight-related conditions specified.

\subsection{Measures of reduction of the homologation road emission of carbon dioxide resulting from the homologation principles}

The reduction of the road emission of carbon dioxide according to the certificate of homologation $\left(\mathrm{E}_{\mathrm{CO} 2}^{\mathrm{TV}}\right)_{\mathrm{i}}$ for a given version of vehicles results from the principle of determining of the homologation value set forth in regulation 692/2008 and regulation 101 (p. 3). Before the homologation tests are conducted the manufacturer usually has several vehicles of a given type ready as understood by regulation $692 / 2008$. In order to utilize this principle the manufacturer should perform preliminary tests of the road emission of $\mathrm{CO}_{2}$ from its vehicles according to the method set forth in regulation 101 then provide for tests the vehicle that is characterized by low emission and declare a value lower by $4 \%$. One of the criterions of the vehicle selection for the homologation tests is the reference mass of this vehicle.

\subsection{Measures of reduction of the homologation road emission of carbon dioxide resulting from the method of measurement}

The value of the road emission of carbon dioxide determined in the laboratory as a result of measurements on a chassis dynamometer in a given cycle depend on many factors, particularly the conditions under which the measurement is carried out (ambient conditions defined by the temperature, humidity ambient pressure, thermal engine state at the beginning of the measurement, motion resistance set on the dynamometer that results in the engine load), the measurement equipment used (type and accuracy level), the accuracy of reflecting of the driving cycle and the properties of the reference fuels. These factors are defined by regulation 101 . The parameters that characterize it have been determined with great tolerances. This causes that test results in individual, otherwise fully compliant laboratories, can be different [9].

The homologation tests of the exhaust emissions as per regulation 715/2007 can be carried out:

- in a laboratory of an authorized technical unit,

- in a laboratory of a manufacturer.

In the fist case the manufacturer has the option of selecting the laboratory, where the homologation tests are to be performed. By choosing the one in which low values of the

\section{4. Środki zmniejszenia homologacyjnej emisji drogowej dwutlenku węgla wynikające $z$ metody pomiaru}

Wartość emisji drogowej dwutlenku węgla określona w laboratorium w wyniku pomiarów na hamowni podwoziowej w danym cyklu jazdy zależy od wielu czynników, w szczególności warunków, w których pomiar jest prowadzony (warunków otoczenia definiowanych przez temperaturę, wilgotność i ciśnienie, stanu cieplnego silnika na początku pomiaru, oporów ruchu ustalonych na hamowni podwoziowej, wpływających na obciążenie silnika), stosowanego wyposażenia pomiarowego (rodzaju, dokładności), dokładności odtwarzania cyklu jazdy, właściwości paliw wzorcowych. Te czynniki definiuje Regulamin 101. Parametry, które je charakteryzują, określono z odpowiednimi tolerancjami, często stosunkowo dużymi. Powoduje to, że wyniki badań emisji w poszczególnych laboratoriach, w pełni zgodnych z ustalonymi wymaganiami, mogą się różnić [9].

Badania homologacyjne emisji zanieczyszczeń według rozporządzenia 715/2007 mogą być prowadzone:

- w laboratorium jednostki technicznej,

- w laboratorium producenta.

W pierwszym przypadku producent ma możliwość wyboru laboratorium, w którym prowadzi badania homologacyjne pojazdu. Przez wybór tego z nich, w którym są uzyskiwane małe wartości emisji dwutlenku węgla można znacznie obniżyć wartość homologacyjną podaną w świadectwie zgodności. W tym celu producent powinien przeprowadzić badania porównawcze emisji między swoim laboratorium a laboratoriami, które potencjalnie mogą być wykorzystane jako prowadzące badania homologacyjne produkowanych pojazdów.

W przypadku drugim jest wymagana zgoda organu upoważnionego do udzielania homologacji. Zazwyczaj uzyskanie takiej zgody nie stanowi problemu. Badania homologacyjne są wtedy prowadzone pod nadzorem ekspertów $\mathrm{z}$ upoważnionej jednostki technicznej (witnessed tests). Taki sposób badań jest coraz częściej stosowany.

Jeśli badania homologacyjne są prowadzone w laboratorium producenta, ma on możliwość optymalizacji warunków pomiaru dla danego pojazdu, a nawet w pewnym stopniu wpływanie na jego wynik przez selektywny dobór wyposażenia pomiarowego. Do warunków pomiaru, których optymalizacja $\mathrm{w}$ ramach dopuszczalnych tolerancji może prowadzić do zmniejszenia określanej emisji drogowej dwutlenku węgla należą przede wszystkim:

- sposób odtwarzania cyklu,

- temperatura i czas kondycjonowania pojazdu przed pomiarem,

- warunki atmosferyczne podczas pomiaru (temperatura, wilgotność i ciśnienie).

Producent może przez porównanie różnych elementów wyposażenia pomiarowego wybrać takie, których parametry zapewniają najniższą wartość określanej emisji dwutlenku węgla, np.:

- objętość spalin (tolerancja $\pm 2 \%$ ), 
emission of carbon dioxide are obtained the manufacturer can significantly reduce the homologation value specified in the certificate of conformity. To this end the manufacturer should also carry out comparative tests between its own laboratory and the laboratories that can potentially be used as the ones carrying out the homologation of the manufactured vehicles.

In the second case a permit issued by a body authorized to perform homologation is required. Obtaining such a permit is not usually a problem. The homologation tests are then conducted by an authorized technical unit as 'witnessed tests'. Such a system is more and more frequently utilized.

If the homologation tests are conducted in the manufacturer's laboratory it has the possibility of optimization of the measurement conditions for a given vehicle and even, to some extent, influence the results by an arbitrary choice of the measuring equipment. The conditions of measurement, whose optimization within the permissible tolerances may lead to a reduction of the determined road emission of carbon dioxide, are first of all:

- the manner of cycle reflection,

- temperature and time of vehicle conditioning before the measurement,

- atmospheric conditions during the measurement (temperature, humidity and ambient pressure).

The manufacturer, through comparison of several measuring pieces of equipment, can select systems whose parameters will ensure the lowest value of the emission of carbon dioxide. The parameters could be:

- exhaust gas volume (tolerance $\pm 2 \%$ ),

- concentration of reference carbon dioxide (tolerance $\pm 2 \%$ )

- concentration of reference carbon dioxide at the outlet of the gas mixer (tolerance $\pm 2 \%$ ).

Sometimes, regulation 101 allows a selection of the conditions by the manufacturer under which the homologation tests are to be performed. The conditions that significantly influence the exhaust emission level (only those that can influence the emission level) are for example:

- the setting of the motion resistance on the chassis dynamometer,

- the method of vehicle cooling,

- reference fuels (for gaseous fuels).

According to regulation 101 the load of the chassis dynamometer can be set:

- based on the actual total vehicle motion resistance determined through coastdown or wheel torque measurement (method A),

- according to an alternative method (the regulations provide the value of force or power absorbed depending on the vehicle reference mass- method B).

Between the motion resistance values determined according to the said methods for some vehicles there are significant differences that influence the road emission of carbon dioxide (Table 3).
- stężenie wzorcowego dwutlenku węgla (tolerancja $\pm 2 \%$ ),

- stężenie wzorcowego dwutlenku węgla na wylocie mieszalnika gazów (tolerancja $\pm 2 \%$ ).

Niekiedy regulamin 101 dopuszcza wybór przez producenta warunków, w których są prowadzone badania homologacyjne. Do warunków wpływających w sposób istotny na poziom emisji zanieczyszczeń, dla których jest to możliwe, należy np.:

- ustawienie oporów ruchu pojazdu na hamowni podwoziowej,

- sposób chłodzenia samochodu,

- paliwa wzorcowe (dla paliw gazowych).

Zgodnie $\mathrm{z}$ regulaminem 101 obciążenie na hamowni podwoziowej może być ustalone:

- na podstawie rzeczywistych całkowitych oporów ruchu pojazdu określonych na drodze metodą wybiegu lub pomiaru momentu obrotowego na kołach (metoda A),

- według tzw. metody alternatywnej (przepisy podają wartość tzw. siły lub mocy pochłanianej w zależności od masy odniesienia pojazdu - metoda B).

Między oporami ruchu określonymi według wymienionych metod występują dla niektórych pojazdów dość znaczne różnice wpływające w istotny sposób na emisję drogową dwutlenku węgla (tab. 3).

W odniesieniu do samochodów kategorii M1 opory ruchu określone według metody A mogą być większe lub mniejsze niż według metody B. Dla kategorii N1 są one zazwyczaj mniejsze w przypadku tej ostatniej (nie dotyczy to samochodów osobowych przebudowanych na dostawcze przez zamontowanie tzw. „kratki”). Wynika to z tego, że opory ruchu według metody alternatywnej są ustalone tylko dla kategorii M1. Dla pojazdów innych o masie odniesienia $\mathrm{RM}>1700 \mathrm{~kg}$ odpowiednie wartości należy pomnożyć przez współczynnik 1,3. Jego wartość jest mała i w związku z tym

Table 3. Comparison of the value of the motion resistance force absorbed by the chassis dynamometer determined based on the measurement on distance (A) and according to alternative method (B) for light duty vehicles at $\mathrm{v}=80 \mathrm{~km} / \mathrm{h}$

Tabela 3. Porównanie wartości sity oporów ruchu pochłanianych przez hamownię podwoziowa, określonych na podstawie pomiaru na drodze (A) $i$ wedtug metody alternatywnej (B) dla samochodów lekkich przy $v=80 \mathrm{~km}$

\begin{tabular}{|c|c|c|c|}
\hline $\begin{array}{l}\text { Category/ } \\
\text { kategoria }\end{array}$ & $\begin{array}{c}\text { Resistance/opory } \\
\text { A [N] }\end{array}$ & $\begin{array}{c}\text { Resistance/opory } \\
\text { B [N] }\end{array}$ & $\begin{array}{l}\text { Difference/ } \\
\text { różnica }[\%]\end{array}$ \\
\hline \multirow[t]{5}{*}{ M1 } & 434 & 315 & 27 \\
\hline & 230 & 270 & -17 \\
\hline & 200 & 252 & -26 \\
\hline & 285 & 284 & 0 \\
\hline & 511 & 410 & 20 \\
\hline \multirow[t]{6}{*}{ N1 } & 340 & 315 & 7 \\
\hline & 338 & 315 & 7 \\
\hline & 580 & 491,4 & 15 \\
\hline & 882 & 503,1 & 43 \\
\hline & 383 & 302 & 21 \\
\hline & 775 & 526,5 & 32 \\
\hline
\end{tabular}


In reference to vehicle in category $\mathrm{M} 1$ the motion resistance determined according to method A could be higher or lower than according to method B. For category N1 they are usually lower in the case of the latter (not applicable for passenger vehicles modified into light duty trucks through a fitting of a 'cargo partition' in the passenger compartment for tax-deduction purposes). It results from the fact that the motion resistance according to the alternative method is set only for category M1. For other vehicles of reference mass $\mathrm{RM}>1700 \mathrm{~kg}$ respective values need to be multiplied by the coefficient of 1.3. Its value is low and hence, such determined motion resistance for the majority of vehicles in category $\mathrm{N} 1$ is lower than the actual one. In the American legislation for the equivalents of these vehicles a coefficient of $1.50-1.58$ is applied.

The vehicle cooling on a chassis dynamometer is done through an air blower. Regulation 83 sets forth three ways of cooling:

- variable air velocity equal to the vehicle speed in the range of $10-120 \mathrm{~km} / \mathrm{h}$,

- variable air velocity equal to the vehicle speed in the range of $0-50 \mathrm{~km} / \mathrm{h}$ (at higher speeds the air velocity is undetermined),

- constant air velocity equal to $6 \mathrm{~m} / \mathrm{s}$.

According to regulation 692/2008 if a vehicle is fueled with LPG the homologation tests should be conducted with the use of two reference fuels being the mixture of propane and butane, marked 1 and 2 . They differ by the content of hydrocarbons (gas 1: propane $-30 \pm 2 \%$ vol., butane - the balance; gas 2: propane $85 \pm 2 \%$ volume, butane - the balance). The only exception is carbon dioxide for which the road emission is determined with the use of one of these fuels selected by the manufacturer.

The manufacturer can select the method of setting of the load on the chassis dynamometer, the cooling method of the vehicle during the measurement and the reference gaseous fuel that is optimum in terms of the emission of carbon dioxide for the homologated vehicle.

\section{The effect of application of non-construction measures}

The effect of application of the said methods resulting from the principles of evaluation set forth in regulations $443 / 2009$ and 510/2011 and the principles of homologation set forth in regulations $692 / 2008$ and 101 on the difference between the homologation value and the permissible value of the road emission of carbon dioxide depends on the interpretation of the discussed principles.

According to the legislation the tolerance of the vehicle weights is $\pm 5 \%$, hence the width of the range mentioned in 4.2 can be $\pm 5 \%$ of the averaged weight for a given version. To date, it has not been required that a vehicle homologated for exhaust emission as per directive $70 / 220 / \mathrm{EEC}$ [10] or regulation 83 [11] and for the fuel consumption and the emission of carbon dioxide as per directive 80/1268/EEC [12] or regulation 101 [8] have an average weight calculated as a representative of a given type as understood in the legislation tak określone opory ruchu są dla dużej części pojazdów kategorii N1 mniejsze od rzeczywistych. W przepisach amerykańskich jest stosowany dla odpowiedników tych pojazdów współczynnik 1,50-1,58.

Chłodzenie pojazdu na hamowni podwoziowej następuje przez nadmuch powietrza przez dmuchawę. Regulamin 83 ustala trzy sposoby tego chłodzenia:

- zmienna prędkość powietrza równa prędkości jazdy w zakresie $10-120 \mathrm{~km} / \mathrm{h}$,

- zmienna prędkość powietrza równa prędkości jazdy w zakresie 0-50 km/h (przy większej prędkości jazdy prędkość powietrza nie jest określona),

- stała prędkość powietrza równa $6 \mathrm{~m} / \mathrm{s}$.

Zgodnie z rozporządzeniem 692/2008 przy zasilaniu LPG badania homologacyjne emisji zanieczyszczeń powinny być prowadzone przy użyciu dwóch paliw wzorcowych stanowiących mieszaninę propanu i butanu, oznaczonych 1 i 2 . Różnią się one zawartością ww. węglowodorów (gaz 1: propan $-30 \pm 2 \%$ obj., butan - reszta; gaz 2: propan $85 \pm 2 \%$ obj., butan - reszta). Wyjątek stanowi dwutlenek węgla, którego emisja drogowa jest określana przy użyciu jednego z tych paliw, wybranego przez producenta.

Producent może wybrać metodę ustawienia obciążenia na hamowni podwoziowej, sposób chłodzenia pojazdu podczas pomiaru i wzorcowe paliwo gazowe optymalne ze względu na emisję dwutlenku węgla dla samochodu przedstawionego do badań homologacyjnych.

\section{Efekty stosowania środków niekonstrukcyjnych}

Efekt zastosowania wymienionych środków wynikających z zasad oceny ustalonych w rozporządzeniach 443/2009 i 510/2011 oraz zasad homologacji ustalonych w rozporządzeniu 692/2008 i regulaminie 101 na różnicę między wartością homologacyjną a dopuszczalną emisji drogowej dwutlenku węgla zależy od sposobu interpretacji omawianych zasad.

Zgodnie z przepisami tolerancja masy samochodów wynosi $\pm 5 \%$, a więc szerokość przedziału, o którym mowa wyżej w punkcie 4.2 , może wynosić $\pm 5 \%$ masy średniej dla danej wersji. Dotychczas nie było wymagane, by samochód przedstawiony do badań homologacyjnych w zakresie emisji zanieczyszczeń według dyrektywy 70/220/EWG [10] lub regulaminu 83 [11] oraz w zakresie zużycia paliwa i emisji dwutlenku węgla według dyrektywy 80/1268/EWG [12] lub regulaminu 101 [8], jako przedstawiciel danego typu w rozumieniu wymienionych przepisów (a więc w przybliżeniu wersji), miał masę średnią. Badania mogły być prowadzone na dowolnym samochodzie o masie mieszczącej się w granicach tolerancji. Gdyby taką interpretację przyjąć w odniesieniu do rozporządzeń 403/2009 i 510/2011, to zastosowanie środków wynikających z zasad oceny i homologacji zmniejsza różnicę między wartością według świadectwa homologacji a dopuszczalną o 4\%, łącznie z efektem zwiększenia $\left(\mathrm{E}_{\mathrm{CO} 2}^{\mathrm{PV}}\right)_{\mathrm{i}}$ oraz efektem zmniejszenia $\left(\mathrm{E}_{\mathrm{CO} 2}^{\mathrm{TV}}\right)_{\mathrm{i}}$. 
(more or less - version). The tests could be conducted on any given vehicle of the weight within the tolerance range. If such an interpretation were to be adopted for regulations $403 / 2009$ and 510/2011 the use of measures resulting from the principles of evaluation and homologation reduces the difference between the value in the certificate of homologation and the permissible one by $4 \%$ including the effect of increase $\left(\mathrm{E}_{\mathrm{CO} 2}^{\mathrm{PV}}\right)_{i}$ and the effect of decrease $\left(\mathrm{E}_{\mathrm{CO} 2}^{\mathrm{TV}}\right)_{i}$.

The total theoretical effect of the use of the discussed measures depends on the vehicle weight. It amounts to approximately $7 \%$ for the smallest vehicles up to $10 \%$ for the largest.

Following another interpretation, practically not yet utilized for homologation we need to assume a vehicle of an average weight for a given version. Then the theoretical effect amounts to only $4 \%$.

For vehicle in category N1 there are additional possibilities of reduction of the road emission of carbon dioxide on the certificate of homologation.

The first one results from the fact that in relation to the homologation the value on the certificate of homologation cannot be lower than the actual one by more than $4 \%$ but in relation to the extension a difference between the actual value and the certificate value of not more than $6 \%$ is admitted. The manufacturer can select the way of homologation and, thus, influence the value on the certificate of homologation. If the actual road emission of $\mathrm{CO}_{2}$ of a new version is higher than the homologated version (not more than $2 \%$ ) then the homologation based on the extension is more beneficial. In that case the value of $\mathrm{CO}_{2}$ road emission on the certificate of homologation will be lower. If, however, the actual road emission of $\mathrm{CO}_{2}$ is lower new homologation is more advantageous.

The second option for the reduction of the road emission of carbon dioxide for vehicle in category $\mathrm{N} 1$ according to the certificate of compliance takes place when a homologation of a family of vehicles is carried out. The homologation according to the first method specified by the legislation (point 3) often used, becomes disadvantageous as it overestimates the average road emission of $\mathrm{CO}_{2}$ for the family. By an appropriate application of the second of the methods specified in the legislation (point 3 ) there is a possibility of reducing
Całkowity teoretyczny efekt zastosowania omawianych środków zależy od masy samochodu. Wynosi on od około $7 \%$ dla najmniejszych samochodów do około $10 \%$ dla największych.

Według innej interpretacji, dotychczas w zasadzie niestosowanej do homologacji, należy przyjąć samochód o średniej masie dla danej wersji. Wtedy teoretyczny efekt wynosi tylko $4 \%$.

Dla pojazdów kategorii N1 występują dodatkowe możliwości zmniejszenia emisji drogowej dwutlenku węgla według świadectwa homologacji.

Pierwsza z nich wynika z tego, że w odniesieniu do homologacji wartość według świadectwa nie może być mniejsza od rzeczywistej więcej niż 4\%, natomiast odnośnie do rozszerzenia dopuszcza się różnicę między wartością rzeczywistą i według świadectwa równą nie więcej niż 6\%. Producent może wybrać sposób homologacji i w ten sposób wpłynąć na wartość według świadectwa. Jeśli rzeczywista emisja drogowa $\mathrm{CO}_{2}$ nowej wersji jest większa niż wersji homologowanej (o nie więcej niż 2\%), to korzystniejsza jest homologacja na zasadzie rozszerzenia. Wtedy wartość emisji drogowej $\mathrm{CO}_{2}$ według świadectwa będzie mniejsza. Jeśli natomiast wartość ta jest mniejsza, to korzystniejsza jest nowa homologacja.

Druga możliwość ograniczenia dla pojazdów kategorii N1 emisji drogowej dwutlenku węgla według świadectwa zgodności występuje wtedy, gdy przeprowadza się homologację rodziny pojazdów. Homologacja według pierwszej metody ustalonej przez przepisy (pkt 3), często obecnie stosowana, staje się niekorzystna, gdyż zawyża średnią emisję drogową $\mathrm{CO}_{2}$ dla rodziny. Przez odpowiednie stosowanie drugiej z metod ustalonych w przepisach (pkt 3 ) istnieje możliwość obniżenia wartości homologacyjnej dla niektórych wersji wchodzących w skład rodziny o kilka procent.

W tabeli 4 zestawiono różnice między minimalną a maksymalną wartością emisji drogowej dwutlenku węgla w sytuacji wystąpienia skrajnych warunków pomiaru w granicach dopuszczalnych tolerancji. Określono je na podstawie badań i analiz kilku pojazdów w teście według regulaminu 101 .

Table 4. Differences between the minimum and maximum values of the road emission of carbon dioxide in the case of occurrence of extreme measurement conditions

Tabela 4. Różnice między minimalną a maksymalna wartością emisji drogowej dwutlenku węgla w sytuacji wystapienia skrajnych warunków pomiaru

\begin{tabular}{|c|c|c|}
\hline Measurement conditions/warunki pomiaru & $\begin{array}{l}\text { Minimum difference*/ } \\
\text { różnica minimalna }[\%]\end{array}$ & $\begin{array}{l}\text { Maximum difference*/ } \\
\text { różnica maksymalna }[\%]\end{array}$ \\
\hline Reflecting of the driving cycle/odtwarzanie cyklu jazdy & 4 & 16 \\
\hline $\begin{array}{l}\text { Temperature and conditioning time before the measurement/temperatura i czas kondycjo- } \\
\text { nowania przed pomiarem }\end{array}$ & 1 & 4 \\
\hline Ambient conditions during the measurement/warunki atmosferyczne podczas pomiaru & 0 & 3 \\
\hline $\begin{array}{l}\text { Method of cooling of the vehicle on the chassis dynamometer/metoda chtodzenia samo- } \\
\text { chodu na hamowni podwoziowej }\end{array}$ & 1 & 3 \\
\hline Setting of the motion resistance/ustawienie oporów ruchu & 0 & 8 \\
\hline Measuring equipment (selected components)/wyposażenie badawcze (wybrane elementy) & 12 & 12 \\
\hline
\end{tabular}


of the homologation value of the emission for some of the versions that are a part of the family by a few percent.

Table 4 presents the differences between the minimum and maximum value of the road emission of carbon dioxide in the case of occurrence of the extreme measurement conditions within the tolerance limits. They have been determined based on the research and analysis of several vehicles during tests as per regulation 101 .

\section{Conclusions}

According to the new integrated EU strategy of the reduction of the carbon dioxide emission - the principal greenhouse gas- from motor vehicles is to be implemented thanks to legal requirements for the manufacturers. To that end, two legal acts have been adopted:

- regulation 443/2009, applicable to vehicles in category M1,

- regulation 510/2011, applicable to vehicles in category N1.

The said regulations assume that the requirements set forth therein will be met as a result of construction related methods and actions leading to a reduction of the actual road emission of carbon dioxide. These are: the application of electric and hybrid powertrains, engines fueled with alternative fuels that contain less carbon than conventional fuels (gasoline and diesel fuel) as well as perfecting the conventional powertrains.

From the analysis of the regulations and legal acts referred to therein it results that for the requirements to be met we can also use measures referred to as 'non-construction' measures. They can be divided onto two groups:

- those that cause an increase of the average permissible road emission of carbon dioxide from vehicles of a given manufacturer,

- those that cause a decrease in the average homologation road emission of carbon dioxide from vehicle of a given manufacturer that can again be divided into measures resulting from the principles of homologation and the method of testing of this exhaust component.

The performed analysis showed that the non-construction measures are effective. In extreme cases for some versions of the vehicles, in theory their effect could be a reduction of the difference between the road emission of carbon dioxide given in the certificate of homologation and the permissible emission by more than $20 \%$. In practice, the average rate of reduction is much lower because:

- it is difficult to perform tests that are fully optimal for a given type of vehicle,

- part of the non-construction measures is constantly applied (whether the testing parties are aware of that or not).

It is estimated that as a result of the application of the nonconstruction methods we can obtain (without much effort) the effects of the order of $5-10 \%$ in the form of reduction of the difference between the average homologation emission and the maximum permissible emission of carbon dioxide. This is on average approximately $100 \%$ of the value by which we should reduce the average emission in 2010 from vehicles in category M1 and approximately $40 \%$ of the value by which

\section{Podsumowanie}

Zgodnie z nową, zintegrowaną strategią UE ograniczenie emisji dwutlenku węgla - podstawowego gazu cieplarnianego - z pojazdów samochodowych ma nastąpić dzięki wprowadzeniu prawnych wymagań dla producentów. W tym celu zostały przyjęte dwa akty prawne:

- rozporządzenie 443/2009, dotyczące samochodów kategorii homologacyjnej M1,

- rozporządzenie 510/2011, dotyczące samochodów kategorii homologacyjnej N1.

Wymienione rozporządzenia zakładają, że spełnienie ustalonych w nich wymagań nastąpi w wyniku działań o charakterze „konstrukcyjnym”, prowadzacych do obniżenia rzeczywistej emisji drogowej dwutlenku węgla, do których zalicza się m.in. zastosowanie napędów elektrycznych i hybrydowych, silników zasilanych paliwami alternatywnymi zawierającymi mniej węgla niż paliwa konwencjonalne: benzyna i olej napędowy oraz doskonalenie pojazdów konwencjonalnych.

$\mathrm{Z}$ analizy rozporządzeń, a także aktów prawnych w nich przywoływanych wynika jednak, że do spełnienia wymagań mogą być także wykorzystane środki, które można określić jako „niekonstrukcyjne”. Można je podzielić na dwie podstawowe grupy:

- powodujące zwiększenie średniej dopuszczalnej emisji drogowej dwutlenku węgla pojazdów danego producenta,

- powodujące zmniejszenie średniej homologacyjnej emisji drogowej dwutlenku węgla pojazdów danego producenta, które z kolei dzielą się na środki wynikające z zasad homologacji i metody badań emisji tego zanieczyszczenia.

Przeprowadzona analiza wykazała, że środki niekonstrukcyjne są efektywne. W przypadku skrajnym dla niektórych wersji pojazdów teoretycznie ich efektem może być zmniejszenie różnicy między emisją drogową dwutlenku węgla podaną w świadectwie homologacji a dopuszczalną o ponad $20 \%$. W praktyce średni stopień zmniejszenia będzie jednak znacznie mniejszy między innymi z tego względu, że:

- trudno jest przeprowadzać badania w sposób w pełni zgodny z optymalnym dla określonego samochodu,

- część środków niekonstrukcyjnych jest, świadomie lub przypadkowo, stosowana.

Szacuje się, że w wyniku stosowania środków niekonstrukcyjnych możliwe jest uzyskanie (bez większych trudności) efektów rzędu 5-10\% w postaci zmniejszenia różnicy między średnią homologacyjną a dopuszczalną emisją drogową dwutlenku węgla. Stanowi to przeciętnie około $100 \%$ wartości, o którą należy obniżyć średnią emisję w 2010 r. z samochodów kategorii M1 i około $40 \%$ wartości, o którą należy obniżyć średnią emisję w 2010 r. z kategorii N1, by osiągnąć poziomy podane w rozporządzeniach 443/2009 i 510/2011. Środki niekonstrukcyjne mogą więc znacznie ułatwić producentom spełnienie ustalonych wymagań. Nie przyczyniają się one jednak w ogóle do obniżenia rzeczywistej emisji 
we should reduce the average emission in 2010 in category $\mathrm{N} 1$ in order to reach the levels given in regulations 443/2009 and 510/2011. The non-construction measures can, thus, significantly facilitate the meeting of the requirements by the manufacturers. They do not at all, however, contribute to the reduction of the actual road emission of carbon dioxide but only affect the values of the indexes for the evaluation of the requirement compliance assumed in the regulations for the evaluation of the requirement compliance. drogowej dwutlenku węgla, lecz wpływają na wartości wskaźników przyjętych w rozporządzeniach do oceny zgodności z wymaganiami.

Paper reviewed/Artykut recenzowany

\section{Bibliography/Literatura}

[1] Regulation (EC) No 443/2009 of the European Parliament and of the Council of 23 April 2009 setting emission performance standards for new passenger cars as part of the Community's integrated approach to reduce $\mathrm{CO} 2$ emissions from light-duty vehicles. OJ L 140/1.

[2] Regulation (EC) No 510/2011 of the European Parliament and of the Council of 11 May 2011 setting emission performance standards for new light commercial vehicles as part of the Community's integrated approach to reduce $\mathrm{CO} 2$ emissions from light-duty vehicles. OJ L 145/1.

[3] Dyrektywa 2007/46/WE Parlamentu Europejskiego i Rady z 5 września 2007 r. ustanawiająca ramy dla homologacji pojazdów silnikowych i ich przyczep oraz układów, części i oddzielnych zespołów technicznych przeznaczonych do tych pojazdów („dyrektywa ramowa”). OJ L 263/1, 9.11.2007.

[4] Regulation (EC) No 715/2007 of the European Parliament and of the Council of 20 June 2007 on type approval of motor vehicles with respect to emissions from light passenger and commercial vehicles (Euro 5 and Euro 6) and on access to vehicle repair and maintenance information. OJ L 171/1, 29.6.2007.

[5] Commission Regulation (EC) No 692/2008 of 18 July 2008 implementing and amending Regulation (EC) No 715/2007 of the European Parliament and of the Council on type approval of motor vehicles with respect to emissions from light passenger and commercial vehicles (Euro 5 and Euro 6) and on access to vehicle repair and maintenance information. OJ L 199/1, 28.7.2008.

[6] European Environmental Agency. Monitoring the $\mathrm{CO} 2$ emissions from new passenger cars in the EU: summary of data for 2010 .
[7] Lundqvist U., Higher Fuel Efficiency and Lower Emissions. PTNSS Congress, Kraków 2007.

[8] United Nations. Agreement concerning the adoption of uniform technical prescriptions for wheeled vehicles, equipment and parts which can be fitted and/or be used on wheeled vehicles and the conditions for reciprocal recognition of approvals granted on the basis of these prescriptions. Addendum 100: Regulation No 101. Uniform provisions concerning the approval of passenger cars equipped with an internal combustion engine with regard to the measurement of the emission of carbon dioxide and fuel consumption. E/ECE/324 ECE/TRANS/505 Rev. 1/Add. 100, 28.02.1997.

[9] Merkisz J., Pielecha J., Radzimirski S.: Pragmatyczne podstawy ochrony powietrza atmosferycznego w transporcie drogowym. Wydawnictwo Politechniki Poznańskiej, Poznań 2009.

[10] Council Directive 70/220/EEC of 20 March 1970 on the approximation of the laws of the Member States relating to measures to be taken against air pollution by gases from positive-ignition engines of motor vehicles. OJ L076, 6.04.1970.

[11] United Nations. Agreement concerning the adoption of uniform conditions of approval and reciprocal recognition of approval for motor vehicle equipment and parts. Addendum 82: Regulation No 83. Uniform provisions concerning the approval of vehicles with regard to the emission of gaseous pollutants by the engine according to engine fuel requirements. E/ECE/324 ECE/TRANS/505 Rev. 1/Add. 82, 9.04.1990.

[12] Council Directive 80/1268/EEC of 16 December 1980 on the approximation of the laws of the Member States relating to the fuel consumption of motor vehicles. Official Journal L 375, 31.12.1980.
Prof. Jerzy Merkisz, DSc., DEng., - Professor in the Faculty of Working Machines and Transportation at Poznan University of Technology.

Prof. Jerzy Merkisz - profesor na Wydziale Maszyn Roboczych i Transportu Politechniki Poznańskiej.

e-mail: jerzy.merkisz@put.poznan.pl

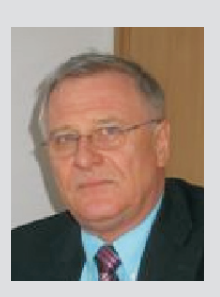

Stanisław Radzimirski, Ass. Prof., DEng. - Associated Professor in the Motor Transport Institute in Warsaw.

Doc. dr inż. Stanisław Radzimirski - docent w Instytucie Transportu Samochodowego w Warszawie.

e-mail: stanislaw.radzimirski@its.waw.pl 